\title{
OBITUARIES
}

Obituaries should be submitted by email to Laura Pacey at I.pacey@nature.com.

All submitted obituaries should be 450 words maximum in length (apart from obituaries for past presidents of the BDA where the length should be 800 words).

Content of the obituary is down to the individual author, and the approval of the family should

be given for the obituary prior to submission to the $B D J$.

\section{DONALD WINSTOCK}

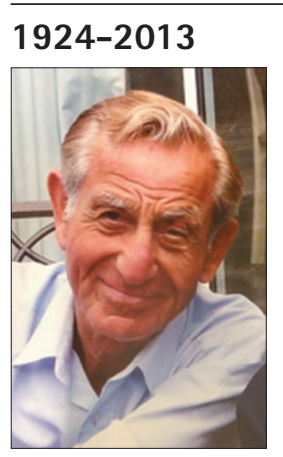

integrity who could adapt to any theatre conditions with minimum equipment, he operated on many patients and achieved good outcomes, though often the cases had been listed as too advanced to operate.

He retired from the NHS in 1989 after 30 years of service as a consultant to four hospitals in London. He loved the theatre, musicals and lying in the sun. He leaves behind his wife, Tess, three children, April, Grant and Adam, and five grandchildren. Both sons followed his footsteps in their respective medical careers.

Saman Warnakulasuriya

\section{PATRICK SWEENEY}

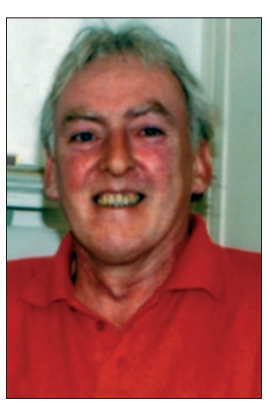

1962-2013

Patrick Coleman Sweeney was the youngest of five children, born on the 18 June 1962 and brought up in Enniskillen. As a son of doctors, Paddy and Nuala, who were strongly

committed to improving inter-community ties in Northern Ireland, he fully appreciated the complexities of the devastation caused by the unrest. His destiny to become a dentist was influenced by his parents' careers but Patrick would have been just as happy in the hospitality industry. As many of us can attest having benefited from delicious meals chez Patrick, he would undoubtedly have been a great success in that field too.

Patrick studied dentistry at Cardiff, graduating in 1984, and as well as becoming a Fellow of the Faculty of Dentistry of the Royal College of Surgeons in Ireland in 1987, he earned two masters degrees and a diploma in dental public health. He worked in the hospital service both in Wales and London and in 1994 was welcomed to Scotland as a trainee in dental public health. Patrick's common sense, dedication to the cause and clinical experience meant that he became an effective and popular consultant in Argyll and Clyde and Forth Valley Health Boards. He led important work on the relationship between deprivation and dental disease, helping shape programmes currently showing unprecedented improvement in child dental health.

Patrick was well known for his wit, intelligence, compassion, generosity, sense of the ridiculous, belief in standing up for the vulnerable and fortitude in the face of adversity. He was also professional, kind, sensitive and gentle; despite this he was able to succeed in a competitive world.

Patrick left Scotland for Bingley to share his life with his partner Robert and often reflected on the wonderful years they had had together up until Robert's sudden death in December 2012 Patrick died on 26 September 2013 aged 51 after suffering a heart attack; he will be greatly missed. The world is a duller place and we will never taste a leg of lamb as well cooked again.

Our deepest sympathy goes to Eoin, John, Janine and Stephanie. Patrick was predeceased by his much loved siblings, Susan and Cormac.

Margie Taylor and Colwyn Jones 